\title{
New Alkaloids from Aconitum stapfianum
}

\author{
Tian-Peng Yin $\cdot$ Le Cai $\cdot$ Ying Li $\cdot$ Yun-Shan Fang $\cdot$ \\ Li Peng $\cdot$ Zhong-Tao Ding
}

Received: 2 September 2015/Accepted: 28 September 2015/Published online: 12 October 2015

(C) The Author(s) 2015. This article is published with open access at Springerlink.com

\begin{abstract}
Nineteen alkaloids, including a new $\mathrm{C}_{19}$-diterpenoid alkaloid stapfianine $\mathrm{A}(\mathbf{1})$ and a new benzamide derivative stapfianine B (2) were isolated from the roots of Aconitum stapfianum. Their structures were established on the basis of extensive spectroscopic analyses (IR, HRESIMS, 1D and 2D NMR).
\end{abstract}

Graphical Abstract

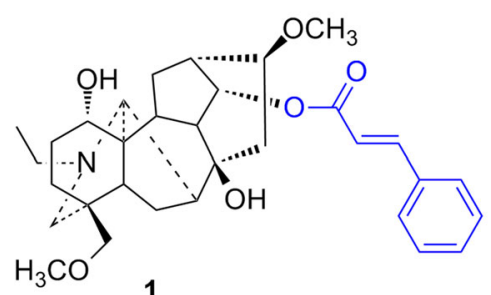

1<smiles>COC(=O)c1cc(O)ccc1NC(=O)c1ccccc1O</smiles>

2

Keywords Aconitum stapfianum - Ranunculaceae $\cdot$ Diterpenoid alkaloid $\cdot$ Benzamide $\cdot$ Stapfianine

\section{Introduction}

Aconitum stapfianum Hand.-Mazz. belongs to the genus Aconitum of the Ranunculaceae, and is distributed mainly at an altitude of 2800-3400 $\mathrm{m}$ in the northwest of Yunnan

Tian-Peng Yin and Le Cai have contributed equally to this work.

Electronic supplementary material The online version of this article (doi:10.1007/s13659-015-0075-1) contains supplementary material, which is available to authorized users.

T.-P. Yin · L. Cai · Y. Li · Y.-S. Fang · L. Peng ·

Z.-T. Ding ( $\square)$

Key Laboratory of Medicinal Chemistry for Nature Resource,

Ministry of Education, School of Chemical Science and

Technology, Yunnan University, Kunming 650091, China

e-mail: ztding@ynu.edu.cn
Province in China [1]. Up to now, only four diterpenoid alkaloids have been isolated from A. stapfianum [2]. As part of our continuous work on the discovery of bioactive ingredients from the Aconitum plants [3, 4], an phytochemical investigation on the roots of A. stapfianum was carried out to afford nineteen alkaloids (Fig. 1), including a new $\mathrm{C}_{19}$-diterpenoid alkaloid stapfianine $\mathrm{A}$ (1), a new benzamide derivative stapfianine B (2), and a known amide 4-oxo-pentanoic acid dimethylamide (3) found in nature for the first time. Their structures were established on the basis of extensive spectroscopic analyses. In this paper, the isolation and structure determination of these alkaloids are described. 


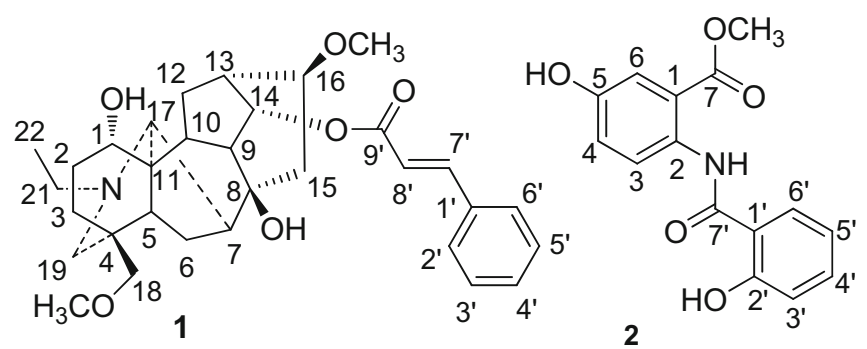<smiles>CCN(CC)C(=O)CCC(C)=O</smiles>

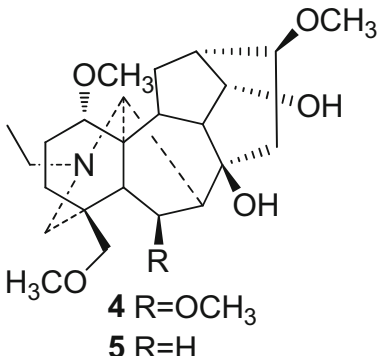

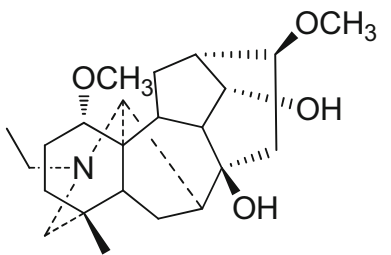

$6 \mathrm{R}=\mathrm{OH}$

$7 \mathrm{R}=\mathrm{OAC}$

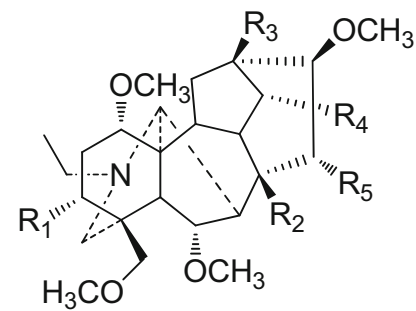<smiles>COc1cc2c(cc1O)[C@H](C)N(C)CC2</smiles>
17<smiles></smiles>
$10 \mathrm{R}=\mathrm{OAs}$

$$
\begin{aligned}
& 11 \mathrm{R}_{1}=\mathrm{R}_{3}=\mathrm{R}_{5}=\mathrm{H}, \mathrm{R}_{2}=\mathrm{OAc}, \mathrm{R}_{4}=\mathrm{OAs} \\
& 12 \mathrm{R}_{1}=\mathrm{R}_{2}=\mathrm{R}_{3}=\mathrm{R}_{4}=\mathrm{R}_{5}=\mathrm{OH}
\end{aligned}
$$$$
13 \mathrm{R}_{1}=\mathrm{H}, \mathrm{R}_{2}=\mathrm{OAc}, \mathrm{R}_{3}=\mathrm{R}_{5}=\mathrm{OH}, \mathrm{R}_{4}=\mathrm{OAs}
$$$$
14 \mathrm{R}_{1}=\mathrm{R}_{3}=\mathrm{OH}, \mathrm{R}_{2}=\mathrm{OAc}, \mathrm{R}_{5}=\mathrm{H}, \mathrm{R}_{4}=\mathrm{OAs}
$$$$
15 \mathrm{R}_{1}=\mathrm{R}_{2}=\mathrm{R}_{3}=\mathrm{OH}, \mathrm{R}_{4}=\mathrm{OAs}, \mathrm{R}_{5}=\mathrm{H}
$$$$
16 \mathrm{R}_{1}=\mathrm{R}_{5}=\mathrm{H}, \mathrm{R}_{2}=\mathrm{OAc}, \mathrm{R}_{3}=\mathrm{OH}, \mathrm{R}_{4}=\mathrm{OBz}
$$<smiles>NCCc1ccc(O)cc1</smiles><smiles>COc1cc2c(cc1O)[C@H](Cc1ccc(O)cc1)N(C)CC2</smiles>

18

Fig. 1 Structures of alkaloids isolated from Aconitum stapfianum

\section{Results and Discussion}

Compound 1 was isolated as a white amorphous powder and its molecular formula was deduced to be $\mathrm{C}_{32} \mathrm{H}_{43} \mathrm{NO}_{6}$ by HRESIMS at $m / z, 538.3169[\mathrm{M}+\mathrm{H}]^{+}$. The NMR spectra of $\mathbf{1}$ showed the presence of a ester carbonyl $\left(\delta_{\mathrm{C}} 166.6 \mathrm{~s}\right)$, a characteristic disubstituted double bond $\left(\delta_{\mathrm{H}} 6.41, \mathrm{~d}\right.$, $\left.J=16.0 \mathrm{~Hz}, 7.65, \mathrm{~d}, J=16.0 \mathrm{~Hz} ; \delta_{\mathrm{C}} 118.0 \mathrm{~d}, 145.4 \mathrm{~d}\right)$ and a mono-substituted benzene $\left(\delta_{\mathrm{H}} 7.36 \mathrm{~m}, 7.36 \mathrm{~m}, 7.50 \mathrm{~m} ; \delta_{\mathrm{C}}\right.$ $128.3 \mathrm{~d}, 129.0 \mathrm{~d}, 130.5 \mathrm{~d}, 134.4 \mathrm{~s})$, which were assigned to a cinnamoyl group [5]. Additionally, an $\mathrm{N}$-ethyl group $\left(\delta_{\mathrm{H}}\right.$ $\left.1.10, \mathrm{t}, J=7.2 \mathrm{~Hz} ; \delta_{\mathrm{C}} 13.1 \mathrm{q}, 48.6 \mathrm{t}\right)$ and two methoxyl groups were identified in the NMR spectra as well. Compound 1 possesses 21 carbons except for the cinnamoyl and methoxyl groups, in combination with biogenetic consideration, suggest that $\mathbf{1}$ might be an aconitine-type $\mathrm{C}_{19^{-}}$ diterpenoid alkaloid [6]. The cinnamoyl group was placed at C-14 according to the HMBC correlation from $\mathrm{H}-14\left(\delta_{\mathrm{H}}\right.$
$5.01, \mathrm{t}, J=4.8 \mathrm{~Hz}$ ) to $\mathrm{C}-9^{\prime}\left(\delta_{\mathrm{C}} 166.6 \mathrm{~s}\right)$ (Fig. 2), while the $\alpha$-orientation of the cinnamoyl group was confirmed by the ROESY correlation between H-10 and H-14. Two methoxyl groups were placed at $\mathrm{C}-16$ and $\mathrm{C}-18$ on the basis of the HMBC correlations from $\mathrm{OCH}_{3}-16\left(\delta_{\mathrm{H}} 3.26, \mathrm{~s}\right)$ to $\mathrm{C}-16\left(\delta_{\mathrm{C}}\right.$ $82.3 \mathrm{~d})$, from $\mathrm{OCH}_{3}-18\left(\delta_{\mathrm{H}} 3.30\right.$, s $)$ to $\mathrm{C}-18\left(\delta_{\mathrm{C}} 79.2 \mathrm{t}\right)$, respectively. In addition, the ROESY correlations between $\mathrm{H}-13$ and $\mathrm{OCH}_{3}-16$ demonstrated the $\beta$-orientation of $\mathrm{OCH}_{3}-16$. A hydroxyl group should be located at C-8 according to the HMBC correlations from H-15, H-6 and H-9 to C-8. Additionally, a signal at $\delta_{\mathrm{H}} 3.74$ was attributed to $\mathrm{H}-1 \beta$, suggesting the presence of an $\mathrm{OH}-1 \alpha[7,8]$, which was further supported by the ROESY correlation between H-1 and H-5. Therefore, the structure of compound $\mathbf{1}$ was determined as stapfianine A, with its assigned NMR data listed in Table 1.

Compound $\mathbf{2}$ was isolated as a white amorphous powder and its molecular formula was deduced to be $\mathrm{C}_{15} \mathrm{H}_{13} \mathrm{NO}_{5}$ 

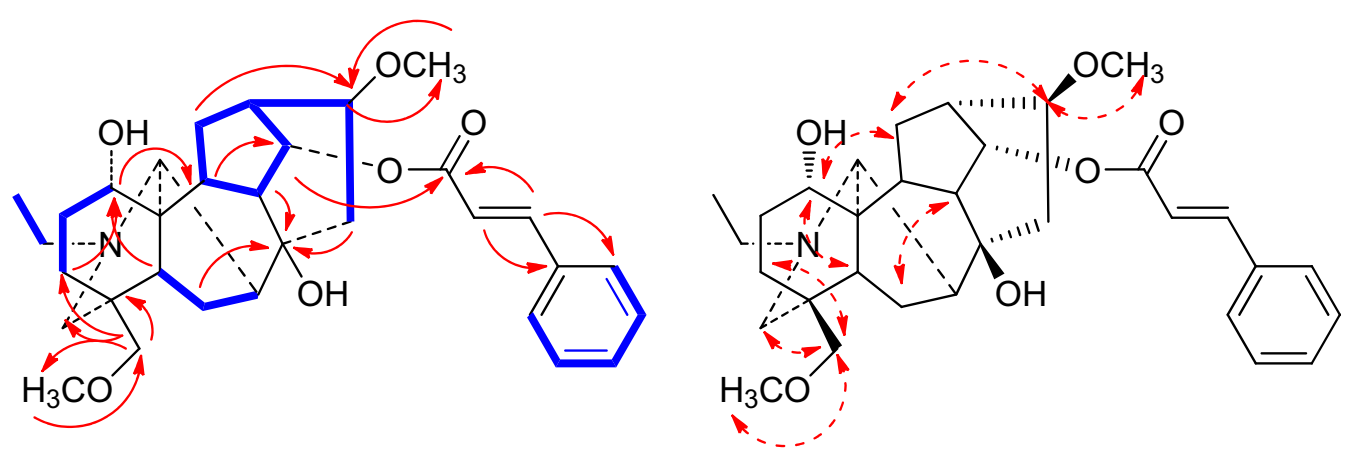

Fig. 2 Key ${ }^{1} \mathrm{H}-{ }^{1} \mathrm{H}$ COSY HMBC $(\rightarrow)$ and ROESY

) correlations of compound $\mathbf{1}$

Table 1 NMR spectroscopic data $\left(400 \mathrm{MHz}\right.$ for ${ }^{1} \mathrm{H}$ and $100 \mathrm{MHz}$ for ${ }^{13} \mathrm{C}, \mathrm{CDCl}_{3}$ ) for compound $\mathbf{1}$

\begin{tabular}{|c|c|c|c|c|c|}
\hline No. & $\delta_{\mathrm{H}} J(\mathrm{~Hz})$ & $\delta_{\mathrm{C}}$ & No. & $\delta_{\mathrm{H}} J(\mathrm{~Hz})$ & $\delta_{\mathrm{C}}$ \\
\hline 1 & 3.74 brs & $72.2 \mathrm{~d}$ & 16 & $3.31 \mathrm{~m}$ & $82.3 \mathrm{~d}$ \\
\hline 2 & $\begin{array}{l}1.59 \mathrm{~m} \\
1.59 \mathrm{~m}\end{array}$ & $27.8 \mathrm{t}$ & 17 & 2.75 brs & $63.8 \mathrm{~d}$ \\
\hline 3 & $\begin{array}{l}1.62 \mathrm{~m} \\
1.88 \mathrm{~m}\end{array}$ & $26.7 \mathrm{t}$ & 18 & $\begin{array}{l}3.13 \mathrm{ABq}(7.4) \\
2.99 \mathrm{ABq}(8.8)\end{array}$ & $79.2 \mathrm{t}$ \\
\hline 4 & & $37.3 \mathrm{~s}$ & 19 & $\begin{array}{l}2.32 \mathrm{ABq}(11.2) \\
2.04 \mathrm{ABq}(11.2)\end{array}$ & $56.6 \mathrm{t}$ \\
\hline 5 & $1.93 \mathrm{~m}$ & $43.5 \mathrm{~d}$ & 21 & $\begin{array}{l}2.50 \mathrm{~m} \\
2.44 \mathrm{~m}\end{array}$ & $48.6 \mathrm{t}$ \\
\hline 6 & $\begin{array}{l}1.84 \mathrm{~m} \\
1.63 \mathrm{~m}\end{array}$ & $25.2 \mathrm{t}$ & 22 & $1.10 \mathrm{t}(7.2)$ & $13.1 \mathrm{q}$ \\
\hline 7 & 2.03 brs & $45.8 \mathrm{~d}$ & $\mathrm{OCH}_{3}-16$ & $3.26 \mathrm{~s}$ & $56.2 \mathrm{q}$ \\
\hline 8 & & $75.0 \mathrm{~s}$ & $\mathrm{OCH}_{3}-18$ & $3.30 \mathrm{~s}$ & $59.5 \mathrm{q}$ \\
\hline 9 & $2.30 \mathrm{~m}$ & $44.8 \mathrm{~d}$ & $1^{\prime}$ & & $134.4 \mathrm{~s}$ \\
\hline 10 & $1.94 \mathrm{~m}$ & $\begin{array}{l}43.6 \mathrm{~d} \\
49.0 \mathrm{~s}\end{array}$ & $\begin{array}{l}2^{\prime}, 6^{\prime} \\
3^{\prime}, 5^{\prime}\end{array}$ & $\begin{array}{l}7.50 \mathrm{~m} \\
7.36 \mathrm{~m}\end{array}$ & $\begin{array}{l}128.3 \mathrm{~d} \\
129.0 \mathrm{~d}\end{array}$ \\
\hline 12 & $\begin{array}{l}2.11 \mathrm{~m} \\
1.73 \mathrm{~m}\end{array}$ & $29.3 \mathrm{t}$ & $4^{\prime}$ & $7.36 \mathrm{~m}$ & $130.5 \mathrm{~d}$ \\
\hline 13 & $2.63 \mathrm{~m}$ & $37.4 \mathrm{~d}$ & $7^{\prime}$ & $7.65 \mathrm{~d}(16.0)$ & $145.4 \mathrm{~d}$ \\
\hline 14 & $5.01 \mathrm{t}(4.8)$ & $77.2 \mathrm{~d}$ & $8^{\prime}$ & $6.41 \mathrm{~d}(16.0)$ & $118.0 \mathrm{~d}$ \\
\hline 15 & $\begin{array}{l}2.34 \mathrm{~m} \\
2.03 \mathrm{~m}\end{array}$ & $42.6 \mathrm{t}$ & $9^{\prime}$ & & $166.6 \mathrm{~s}$ \\
\hline
\end{tabular}

with an unsaturation degree of ten by HRESIMS at $\mathrm{m} / \mathrm{z}$ $310.0673[\mathrm{M}+\mathrm{Na}]^{+}$. The ${ }^{1} \mathrm{H}-\mathrm{NMR}$ spectrum of $\mathbf{2}$ showed signals of a methoxyl group $\left(\delta_{\mathrm{H}} 3.95, \mathrm{~s}\right)$, a 1,2,4-trisubstituted aromatic $\operatorname{ring}\left(\delta_{\mathrm{H}} 7.11, \mathrm{dd}, J=8.8 \mathrm{~Hz}, 2.4 \mathrm{~Hz}\right.$; $7.54, \mathrm{~d}, J=2.4 \mathrm{~Hz} ; 8.63, \mathrm{~d}, J=8.8 \mathrm{~Hz}$ ), and a 1,2 -disubstituted aromatic $\operatorname{ring}\left(\delta_{\mathrm{H}} 7.01, \mathrm{~d}, J=8.4 \mathrm{~Hz} ; 7.43\right.$, t,
$J=7.6 \mathrm{~Hz} ; 6.96, \mathrm{t}, \quad J=7.6 \mathrm{~Hz} ; 7.76, \mathrm{~d}, J=8.0 \mathrm{~Hz}$ ) (Table 2). The ${ }^{13} \mathrm{C}-\mathrm{NMR}$ spectrum revealed 15 carbons resonances, corresponding to the above protonated units and two carbonyl groups $\left(\delta_{\mathrm{C}} 168.8 \mathrm{~s}, 168.9 \mathrm{~s}\right)$. The data summarized above, in combination with biogenetic consideration, suggested that compound 2 might be a benzamide derivatives $[9,10]$. A methyl ester group was placed at $\mathrm{C}-2$ on the basis of the $\mathrm{HMBC}$ correlations from $\mathrm{OCH}_{3}$ 7, H-3 to C-7 ( $\delta_{\mathrm{C}} 168.9 \mathrm{~s}$ ), and H-6 to C-2 (Fig. 3). Two hydroxyl groups could be located at $\mathrm{C}-4$ and $\mathrm{C}-2^{\prime}$ on the basis of the HMBC correlations from H-6, H-3 to C-4, and $\mathrm{OH}-2^{\prime}$ to $\mathrm{C}-2^{\prime}$, respectively. A quaternary carbon $\left(\delta_{\mathrm{C}}\right.$ $134.4 \mathrm{~s})$ ortho to the methyl ester was assigned to connect with the $\mathrm{N}$-atom of the amide group, which caused strong hydrogen bonding between $-\mathrm{NH}\left(\delta_{\mathrm{H}} 11.94\right.$, s $)$ and the carbonyl of the ester [11]. Similarly, the downfield shift of $\mathrm{OH}-2\left(\delta_{\mathrm{H}} 12.34\right.$, s) caused by intramolecular hydrogen bonding between the amide carbonyl and $\mathrm{OH}-2^{\prime}$ suggested that the amide group connected with $\mathrm{C}-1^{\prime}$, which was further supported by the HMBC correlation from $\mathrm{H}-6^{\prime}$ to C-7' and the ROESY correlation between H-6 and $-\mathrm{NH}$ [12]. Therefore, the structure of compound $\mathbf{2}$ was determined as stapfianine B, with its assigned NMR spectroscopic data listed in Table 2.

Based on spectroscopic analyses and comparison with the literature, the known alkaloids were identified as 4-oxopentanoic acid dimethylamide (3) [13], 6-epichasmanine (4) [14], talatisamine (5), sachaconitine (6), 14-acetylsachaconitine (7) [15], franchetine (8), vilmorrisine (9) [16], kongboendine (10) [17], vilmorrianine C (11), aconine (12) [18], crassicauline A (13) [19], yunaconitine (14), 8-deacetylyunaconnitine (15) [15], chasmaconitine (16), $\mathrm{N}$ methylisosalsoline (17) [20], (-)-N-methylcoclaurine (18) [21] and tyramine (19) [22]. Compound 3 was isolated for the first time from a natural source in this study. Besides, compounds 4, 6-12, 15-19 were isolated from this species for the first time. 
Table 2 NMR spectroscopic data (400 MHz for ${ }^{1} \mathrm{H}$ and $100 \mathrm{MHz}$ for ${ }^{13} \mathrm{C}, \mathrm{CDCl}_{3}$ ) for compound 2

\begin{tabular}{|c|c|c|c|c|c|}
\hline No & $\delta_{\mathrm{H}} J(\mathrm{~Hz})$ & $\delta_{\mathrm{C}}$ & No & $\delta_{\mathrm{H}} J(\mathrm{~Hz})$ & $\delta_{\mathrm{C}}$ \\
\hline 1 & & $134.4 \mathrm{~s}$ & $1^{\prime}$ & & $115.3 \mathrm{~s}$ \\
\hline 2 & & $117.1 \mathrm{~s}$ & $2^{\prime}$ & & $162.2 \mathrm{~s}$ \\
\hline 3 & $7.54 \mathrm{~d}(2.4)$ & $117.2 \mathrm{~d}$ & $3^{\prime}$ & $7.01 \mathrm{~d}(8.4)$ & $118.8 \mathrm{~d}$ \\
\hline 4 & & $151.4 \mathrm{~s}$ & $4^{\prime}$ & $7.43 \mathrm{t}(7.6)$ & $134.6 \mathrm{~d}$ \\
\hline 5 & $7.11 \mathrm{dd}(8.8,2.4)$ & $122.2 \mathrm{~d}$ & $5^{\prime}$ & $6.96 \mathrm{t}(7.6)$ & $119.4 \mathrm{~d}$ \\
\hline 6 & $8.63 \mathrm{~d}(8.8)$ & $122.7 \mathrm{~d}$ & $6^{\prime}$ & 7.76 d (8.0) & $126.2 \mathrm{~d}$ \\
\hline 7 & & $168.9 \mathrm{~s}$ & $7^{\prime}$ & & $168.8 \mathrm{~s}$ \\
\hline \multirow[t]{2}{*}{$\mathrm{OCH}_{3}-7$} & $3.95 \mathrm{~s}$ & $52.9 \mathrm{q}$ & $\mathrm{NH}$ & $11.94 \mathrm{~s}$ & \\
\hline & & & $\mathrm{OH}-2^{\prime}$ & $12.34 \mathrm{~s}$ & \\
\hline
\end{tabular}

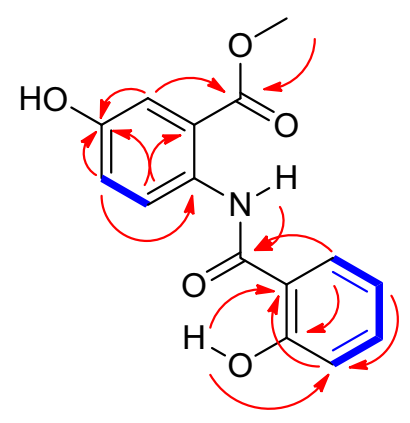<smiles>COC(=O)c1cc(O)ccc1N(C)C(=O)c1c(C)cccc1O</smiles>

Fig. 3 Key ${ }^{1} \mathrm{H}_{-}{ }^{1} \mathrm{H}$ COSY

$(\cdots, \cdots)$ correlations of compound 2

\section{Experimental Section}

\subsection{General Experimental Procedures}

Optical rotation was measured with a Jasco P-1020 digital polarimeter (JASCO, Tokyo, Japan). A Shimadzu UV-Vis 2550 spectrometer (Shimadzu, Kyoto, Japan) was used for collection of UV spectra. NMR spectra were acquired with a Bruker AM-400 spectrometer (Bruker, Karlsruhe, Germany) using TMS as the internal reference. A Nicolet Magna-IR 550 spectrometer (Thermo Nicolet, Madison, USA) was used for scanning IR spectroscopy with $\mathrm{KBr}$ pellets. Melting points were determined on a XRC-1 Melting Point Apparatus (Sichuan University Science Instrument, Chengdu, China) and were not corrected. ESIMS analyses were recorded with an Agilent G3250AA (Agilent, Santa Clara, USA) and Auto Spec Premier P776 spectrometer (Waters, Milford, USA). Silica gel (200-300 mesh and 300-400 mesh; Qingdao Marine, Qingdao, China) and Sephadex LH-20 (GE Healthcare, Fairfield, USA) were used for column chromatography (CC). GF254 plates (Qingdao Marine, Qingdao, China) were used for thin layer chromatography, and spots were visualized by spraying with modified Dragendorff's reagent or $10 \%$ $\mathrm{H}_{2} \mathrm{SO}_{4}$ in ethanol followed by heating.

\subsection{Plant Material}

Roots of A. stapfianum were collected from Dali Bai Autonomous Prefecture of Yunnan Province in China in December 2012, and identified by professor Shu-Gang Lu from School of Life Sciences, Yunnan University. A voucher specimen (2012-yc-2) is deposited in the Key Laboratory of Medicinal Chemistry for Natural Resource, Ministry of Education, and Kunming, China.

\subsection{Extraction and Isolation}

Air-dried and powdered roots $(8.0 \mathrm{~kg})$ of A. stapfianum were percolated with $0.5 \% \mathrm{HCl}$. The aqueous acidic solution was basified with ammonia (10\%) to $\mathrm{pH} 9.0$ and then extracted with EtOAc. Removal of the solvent under reduced pressure afforded the total crude alkaloids (85 g) as yellowish amorphous powder.

The total alkaloids were subjected to silica gel CC eluted with $\mathrm{CHCl}_{3}-\mathrm{CH}_{3} \mathrm{OH}$ gradient system (100:1 to 1:1) to give nine fractions (FrA-FrI). FrA (38.0 g) was further subjected to silica gel CC [petroleum ether (PE)-acetonediethylamine, 100:5:1 to 100:20:1] to give five fractions (FrA1-FrA5). Further silica gel CC purification of FrA1 $(0.7 \mathrm{~g})$ was accomplished by elution with $\mathrm{PE}$-acetone-diethylamine, (100:5:1 to 100:10:1) to afford compounds 6 $(2.0 \mathrm{mg})$ and $7(2.0 \mathrm{mg})$. FrA2 $(4.7 \mathrm{~g})$ was subjected to silica gel CC (PE-acetone-diethylamine, 100:10:1) to yield $\mathbf{1}(12.0 \mathrm{mg}), \mathbf{4}(37.0 \mathrm{mg})$ and $\mathbf{5}(3.5 \mathrm{~g})$. FrA3 (0.9 g) was subjected to silica gel $\mathrm{CC}\left(\mathrm{CHCl}_{3}-\mathrm{CH}_{3} \mathrm{OH}, 20: 1\right)$ to yield compounds $\mathbf{1 1}(12.0 \mathrm{mg})$ and $\mathbf{1 3}(132.0 \mathrm{mg})$. FrA5 (27.0 g) was subjected to silica gel CC (PE-acetone-diethylamine, 100:5:1 to 100:20:1) to yield compounds $14(23.0 \mathrm{~g})$. Further silica gel CC purification of $\operatorname{FrC}(4.2 \mathrm{~g})$ was accomplished by elution with $\mathrm{PE}$-acetone-diethylamine, (100:10:1 to 100:20:1) to afford $\mathbf{1 5}(3.5 \mathrm{~g}), \mathbf{1 6}(3.0 \mathrm{mg})$ and $17(36.5 \mathrm{mg})$. FrE $(1.9 \mathrm{~g})$ was subjected to silica gel $\mathrm{CC}\left(\mathrm{CHCl}_{3}-\mathrm{CH}_{3} \mathrm{OH}, 30: 1\right.$ to $\left.5: 1\right)$ to yield compounds 2 
(14.0 mg) and 3 (13.5 mg). FrF (2.7 g) was subjected to silica gel CC (PE-acetone-diethylamine, 100:5:1) to yield compounds 8 (2.0 mg), 9 (3.5 mg), and $\mathbf{1 0}$ (2.5 mg). FrG $(0.7 \mathrm{~g})$ was subjected to silica gel CC (PE-acetone-diethylamine, $100: 5: 1$ to $100: 10: 1)$ to yield compounds $\mathbf{1 8}$ (8.5 mg), 19 (2.5 mg), and 12 (25.0 mg).

\subsection{Stapfianine A (1)}

White amorphous powder; m.p. $76-77{ }^{\circ} \mathrm{C},[\alpha]_{\mathrm{D}}^{20}+4.19$ (c 2.5, $\left.\mathrm{CH}_{3} \mathrm{OH}\right)$, IR $\left(\mathrm{KBr}, \mathrm{cm}^{-1}\right): v_{\max } 3437,2927,2354$, $1714,1633,1452,1175,1101$. For ${ }^{1} \mathrm{H}-$ and ${ }^{13} \mathrm{C}-\mathrm{NMR}$ spectroscopic data, see Table 1. HRESIMS $m / z$ : 538.3169 $[\mathrm{M}+\mathrm{H}]^{+}$(calcd for $\mathrm{C}_{32} \mathrm{H}_{44} \mathrm{NO}_{6}, 538.3163$ ).

\subsection{Stapfianine B (2)}

Yellow amorphous powder; m.p. $128-130{ }^{\circ} \mathrm{C}$; IR $(\mathrm{KBr}$, $\left.\mathrm{cm}^{-1}\right): v_{\max } 3420,1695,1645,1612,1524,1444,1230$, 1069, 979. For ${ }^{1} \mathrm{H}$ - and ${ }^{13} \mathrm{C}-\mathrm{NMR}$ spectroscopic data, see Table 2. HRESIMS $m / z: 310.0673[\mathrm{M}+\mathrm{Na}]^{+}$(calcd for $\left.\mathrm{C}_{15} \mathrm{H}_{13} \mathrm{NO}_{5} \mathrm{Na}, 310.0691\right)$.

Acknowledgments This project was financially supported by grants from the National Natural Science Foundation of China (No. 81460648), the Program for Changjiang Scholars and Innovative Research Team in University (No. IRT13095) and from the Postgraduate Foundation of Yunnan University (No. YNUY201415).

\section{Compliance with Ethical Standards}

Conflict of Interest The authors declare no conflict of interest.

Open Access This article is distributed under the terms of the Creative Commons Attribution 4.0 International License (http:// creativecommons.org/licenses/by/4.0/), which permits unrestricted use, distribution, and reproduction in any medium, provided you give appropriate credit to the original author(s) and the source, provide a link to the Creative Commons license, and indicate if changes were made.

\section{References}

1. Institute of Botany, Chinese Academy of Science, Institute of Materia Medica and Chinese Academy of Medical Sciences, Flora reipublicae populais sinica, vol. 27 (Science Press, Beijing, 1979), p. 248

2. P.G. Xiao, F.P. Wang, F. Gao, L.P. Yan, D.L. Chen, Y. Liu, Acta Phytotaxon. Sin. 44, 1 (2006)

3. T.P. Yin, L. Cai, H.X. Fang, Y.S. Fang, Z.J. Li, Z.T. Ding, Phytochemistry 116, 314 (2015)

4. T.P. Yin, L. Cai, G. Lei, J.W. Dong, Y.X. Liu, Z.T. Ding, Chin. J. Org. Chem. 33, 2528 (2013)

5. H. Yan, D.L. Chen, X.X. Jian, F.P. Wang, Helv. Chim. Acta 90, 1133 (2007)

6. F.P. Wang, Q.H. Chen, X.Y. Liu, Nat. Prod. Rep. 27, 529 (2010)

7. T.P. Yin, L. Cai, J.M. He, J.W. Dong, H.X. Fang, H. Zhou, Z.T. Ding, J. Asian Nat. Prod. Res. 16, 345 (2014)

8. C.S. Peng, D.L. Chen, Q.H. Chen, F.P. Wang, Chin. J Org. Chem. 25, 1235 (2005)

9. L.M. Sun, H.L. Huang, W.H. Li, Z.D. Nan, G.X. Zhao, C.S. Yuan, Helv. Chim. Acta 92, 1126 (2009)

10. J. Zhang, G.B. Sun, Q.F. Lei, G.Z. Li, J.C. Wang, J.Y. Si, Acta Pharm. Sin. 49, 1150 (2014)

11. J.G. Diaz, J.L. Marapara, F. Valdes, J.G. Sazatornil, W. Herz, Phytochemistry 66, 733 (2005)

12. T.H. Lee, Y.C. Chen, C.K. Lee, C.C. Kuo, H.S. Chang, C.Y. Chao, J.J. Lin, L.C. Lo, Y.H. Kuo, Nat. Prod. Commun. 8, 827 (2013)

13. D. Hüerländer, R. Fröhlich, G. Erker, J. Chem. Soc., Dalton Trans., 1513 (2002)

14. Z.B. Li, F.P. Wang, Chin. Chem. Lett. 7, 443 (1996)

15. T.X. Tang, D.L. Chen, F.P. Wang, Chin. J. Org. Chem. 34, 909 (2014)

16. F.P. Wang, Z.B. Li, X.P. Dai, C.S. Peng, Phytochemistry 45, 1539 (1997)

17. D.L. Chen, Q.H. Chen, X.X. Jian, F.P. Wang, Nat. Prod. Res. Dev. 14, 6 (2001)

18. J.B. Hanuman, A. Katz, Phytochemistry 36, 1527 (1994)

19. F.P. Wang, X.T. Liang, Planta Med. 51, 443 (1985)

20. A. EI-Shazly, M. Wink, Z. Naturforsch. 58, 477 (2003)

21. Y. Kashiwada, A. Aoshima, Y. Ikeshiro, Y.P. Chen, H. Furukawa, M. Itoigawa, T. Fujioka, K. Mihashi, L.M. Cosentino, S.L. MorrisNatschke, K.H. Lee, Bioorg. Med. Chem. 13, 443 (2005)

22. E.E. Elgorashi, S.E. Drewes, J. Van Staden, Phytochemistry 56, 637 (2001) 